\title{
IRONIA ON PARADOKSIN MUOTO
}
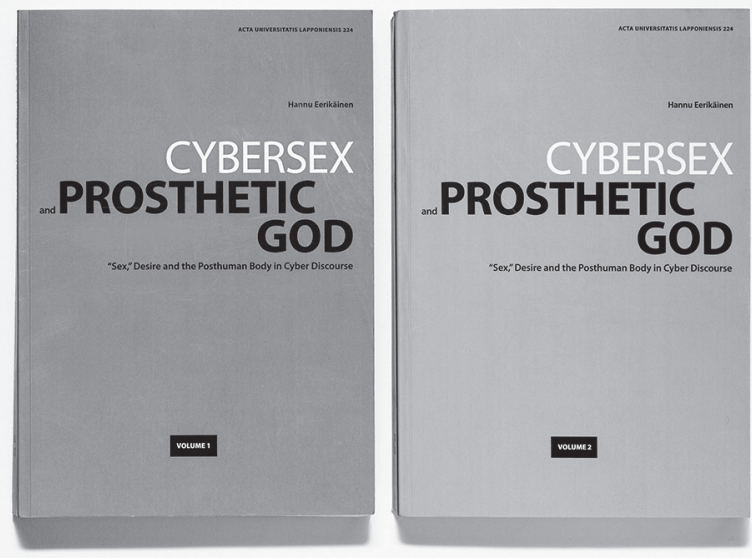

"Dhe Lärdes Öde är ett stadigt Op och Neer!" Olof Wexonius, 1600-luvun lopun ruotsalainen barokkirunoilija, kiteytti "Melancholie"-runossaan. Hannu Eerikäisen (s. 1947) odysseia Lapin yliopiston mediatutkijasta Frankfurt an der Oderin Europa-Universität Viadrinan wissenschaftlicher Mitarbeiteriksi ja lopulta vapaaksi tutkijaksi Berliiniin on ollut Skyllaa ja Kharybdista uhmaava purjehdus, josta hän lopulta rantautui onnekkaasti Rovaniemelle esittämään tarkastettavaksi 1784-sivuisen, kahtena volyymina painetun tyylikkään väitöskirjansa Cybersex and Prosthetic God. "Sex," Desire and the Posthuman Body in Cyber Discourse Lapin yliopiston taiteiden tiedekunnassa 28.11.2014. Väittelijän ja vastaväittäjän, professori Altti Kuusamon, yli neljän tunnin postmodernia eritellyt ja puntaroinut keskustelu oli innostava. Työ hyväksyttiin arvosanalla laudatur.

Vuosien varrella Eerikäinen on lähettänyt minulle Berliinistä lukemattomia tekstiviestejä, jotka ovat koskeneet intellektuaalista kamppailua ja leipää. Niissä kohtalo on ollut milloin "Op" milloin "Neer". Kiinnitin huomiota monien tekstiviestien filosofiseen nasevuuteen ja kielellisiin oivalluksiin, joissa Eerikäinen leikitteli suomen- tai saksankielen ilmaisuilla. Säilöin näitä viestejä käsipuhelimieni muistiin, ja lisäksi silloin tällöin kopioin niitä päiväkirjaani. Onneksi, sillä nykyinen sim-korttini ei enää avaakaan ensimmäisen kapulani tiedostoja.

Eerikäisen tekstiviestifragmentit ja -ideat, SMS Fragmente und Ideen Friedrich Schlegeliä mukaillen, ovat purkavaa ja kiteytyvää filosofiaa. Ne ovat samalla lyhyt johdatus hänen massiivisen postmodernia kulttuuria ja kieltä koskevan tutkimuksensa lähtökohtiin. Valitsemani tekstiviestifragmentit pureutuvat Freudiin, Heideggeriin ja kyberdiskurssiin - erityisesti Donna Harawayn tieteiskuvitelmiin - filosofisesti tihentäen tai räjäyttäen iloisen tieteen tyyliin.

"Heideggerin radikaalisuus on siinä, että hän halusi aloittaa filosofian kokonaan alusta, esisokraattisesta ajasta, ja palaamalla Kreikkaan lopettaa filosofian."(H. E.: 18.8.2008 klo 14.31.:03) "Totta, kyborgi on Freudin 'proteesijumalan' postmoderni inkarnaatio. Jokaiselle oma proteesinsa! Ja rikkaille kaksi!" (H. E.: 9.5.2009 klo 11.48:23)

Eerikäisellä on taiteilijan asenne työhönsä.Hänen kirjansa ja tekstiviestifilosofointinsa motoksi sopiikin Schlegelin ajatussirpale:"Ironie ist die Form des Pradoxen. Paradox ist alles, was zugleich gut und gross ist." (Kritische Fragmente, § 48, 1797) 